\title{
Strategic Risk Factors for Indian Stock Markets
}

\author{
Aman Srivastava1, Prashant Gupta1, Rakesh Gupta ${ }^{2}$ \\ ${ }^{1}$ International Management Institute (IMI), New Delhi, India \\ ${ }^{2}$ Institute of Management \& Technology (IMT), Ghaziabad, India \\ Email:aman@imi.edu, prashantgupta@imi.edu,rgupta@imt.edu
}

How to cite this paper: Srivastava, A. Gupta, P. and Gupta, R. (2017) Strategic Risk Factors for Indian Stock Markets. Theoretical Economics Letters, 7, 1687-1701. https://doi.org/10.4236/tel.2017.76114

Received: August 21, 2017

Accepted: September 27, 2017

Published: September 30, 2017

Copyright (c) 2017 by authors and Scientific Research Publishing Inc. This work is licensed under the Creative Commons Attribution International License (CC BY 4.0).

http://creativecommons.org/licenses/by/4.0/

\section{cc) (i) Open Access}

\begin{abstract}
The present study intends to find out the strategic risk factors and their influence on the Indian capital market (stock market) by using monthly time series data from April 1999 to March 2015. It used factor analysis, lag length analysis, break point test, unit root test and Johansen conintegration analysis. Results show that global financial markets, price-earnings ratio, inflation, industrial production, forex rate and dividend yield have significant impact on Indian stock markets. The short run analysis suggests that Indian stock prices are adjusted monthly by its previous month levels as well as previous month's global stock markets and consumer price index (inflation) in short run (monthly) basis. The study concludes that in long run global financial markets, price-earnings ratio, inflation, industrial production, forex rate and dividend yield acts as source of systematic risk factor for Indian stock markets while in short run previous levels of stock market and inflation acts as systematic risk factor for Indian stock markets.
\end{abstract}

\section{Keywords}

Systematic Risk Factors, Stock Market, Security Return, Macroeconomic Factors

\section{Introduction}

The understanding of risk and its sources has been a serious area of concern for investors while making their investment decisions. For long scholars have been putting efforts to identify the risk factors for stock markets as equity risk premium can be quantified only after identifying these risk factors. The available literature of risk in the area of finance classifies risk factors in to two categories: systematic risk factors and unsystematic risk factors. Classification of this type of risk is done from portfolio diversification perspective and standard deviation of 
total returns has been taken as a proxy of total risk. Total risk is further classified into unsystematic and systematic risk factors. The systematic risk is also termed as market risk in finance literature and is defined as risk coming from external environment or market that affect all firms irrespective of their individual performance. This risk is also defined as uncontrollable risk. On the other hand, unsystematic risk factors are unique risk factors and specific to performance of individual firms. Systematic risk is considered as non-diversifiable risk while unsystematic risk is considered as diversifiable risk. It is also believed that expected return to any investor is a function of systematic risk and an investor is compensated for taking systematic risk.

The available literature observed that asset pricing theories talks about risk factors but failed to identify the exact risk factors for stock markets. There is no consensus among the scholars about the rational of selecting a set of risk factors and number of risk factors. Ross [1] propounded the arbitrage pricing theory and suggested that returns are expected from all investments and range of factors affect these returns but he could not specified the exact factors. Roll and Ross [2] extended this work and identified some factors affecting expected returns of a security. These factors were industrial production, term structure of interest rates, inflation and risk premiums. In Indian context there is no concluding study that could identify systematic risk factors for Indian stock markets. In other study, Alexander et al. [3] mentioned that Arbitrage Price Theory (APT) assumes that some or other unknown risk factors are associated with all expected returns on security. None of these studies are conclusive and could not specify the exact systematic risk factors for stock markets.

\section{Review of Literature}

Asset pricing theories explains the relationship between risk and returns but no asset pricing theories specify the risk factor that drives the stock returns. Asset pricing models of Sharpe [4], Linter [5] and Black [6] has long followed by researchers for establishing relationship between risk and return. Researchers worldwide have applied asset pricing models given by either the single index model or Sharp's capital asset pricing model [4] and Linter [5] or Black [6]. Shrape [4] and Mossin [7] used equity beta as a proxy of market risk. In Arbitrage Price Theory, Ross's [1] explains the impact of macroeconomic factors on long term returns of stocks. Linear function of macroeconomic factors depicts the expected return of any security in APT. Roll and Ross [2] using the data of 1962-72 found at least three and probably four factors affecting stock returns. But they failed to explain the nature and numbers of these factors affecting the return generating process. Stattman [8] and Rosenberg, Reid and Lanstein [9] found in a study done on US stocks that book value of equity to market value of equity ratio and average returns are positively correlated. Chen, Ross and Roll [10] examined the validity of APT in US markets. They used US macroeconomic factors as a proxy of systematic risk factors and they found that industrial pro- 
duction index, wholesale price index, risk premium and slope of yield curve have significant impact of stock returns in US markets. Later these findings were examined in UK markets and same results were also validated in UK markets. In their study it was found that any variation in beta value is flat with respect to size and average return. Darrat and Mukherjee [11] studied macroeconomic factors and Indian stock market returns using vector auto regression (VAR) model. In their study they found a casual linkage between these variables. Chan et al. [12] in a study found that asset pricing theories are not able to identify the systematic risk factors that can explain the stock returns. Chan, Hamao and Lakonishok [12] examined the relationship between stock return and book to price value of equity for Japanese markets and they found that book to market value of equity explains cross section of returns in Japanese markets. Poon and Taylor [13] in a study of UK stock markets, used monthly data of macroeconomic variables industrial production, unanticipated inflation, risk premium, term structure of interest rate and found that these variables have no impact on stock markets. Fama and French [14] captured the cross-sectional variation of stock returns with market beta, size, leverage, book to market equity and earning price ratio. Mukharjee and Naka [15] tested the relationship between six macro-economic variables and stock market returns of Japanese stock markets by employing vector error correction model. Naka, Mukherjee and Tufte [16] investigated the relationship between macroeconomic variable and Indian stock market returns and they found that long term equilibrium exists.

Gjerde and Saettem [17] examined the casual relationship between macroeconomic factors and stock market returns in Norway and found strong linkage between crude oil prices and stock returns. Panda and Kamaiah [18] found a significant relation between stock returns whole sale price index and real economic activity. Flannery and Protopapadakis [19] found that balance of trade, housing related data, consumer price index, employment rate, money supply and producer's price index significantly influences stock returns in US markets. Wongbangpo and Sharma [20] examined and found in Asian markets (Malaysia, Indonesia, Philippines, Singapore and Thailand) a long term relationship between economic growth and stock market, They found that past and present macroeconomic variations explains the stock market. Mukhopadhyay and Sarkar [21] studied the linkage between Indian stock market returns and macroeconomic factors before and after liberalisation. They analysed this relation by taking real economy activity, inflation, money supply growth, nominal exchange rate, FDI and NASDAQ index. They found some of these variables were able to explain stock market return of Indian stocks. Maghrebi, Holmes and Pentecost [22] examined stock market volatility and currency depreciation and they found that stock market volatility is more sensitive to currency depreciation than appreciation. They found that bad news makes stock market more volatile than good news. Dash and Dinesh [23] examined the casual relation between macroeconomic variables on mutual funds returns of India and they found that macroeconomic variables like inflation, crude oil prices, MIBOR, rupee dollar ex- 
change rate significantly influenced stock markets in India. Kim and Nguyen [24] in a study examined the impact of news related with interest rate increase and found that the news does not affect stock return but increases stock market volatility. Srivastava [25] studied the impact of domestic macroeconomic factors on stock market returns. Basu and Chawla [26] applied the multi-factor Arbitrage Pricing Theory (APT) to study portfolio returns and selected macroeconomic variables and found that APT is a good fit in India. Wenjen Hsieh [27] examined the impact of macroeconomic factors on New Zealand stock market using GARCH model and found that New Zealand stock market positively respond to real GDP and world stock market index. Although some researchers like Pethe and Karnik [28], Bhattacharya and Mukherjee [29], Ahmed [30], Srivastava [25] and Pal and Mittal [31] attempted to identify economic factors affecting stock market in India but none of these are conclusive. In Indian contest negligible amount of research has been done for identifying systematic risk factors for Indian stock markets. Shiva and Sethi [32] investigated the relationship among gold prices, SENSEX, NIFTY and USD/INR exchange rate using data for the period January 1998 to 2014 and they found the presence of unidirectional causality that runs gold prices to NIFTY and gold prices to USD/INR exchange rate. The review of literature suggests that although different studies used different countries, data, time period and methodologies but the major risk factors suggested for analysing stock markets are inflation, interest rates, exchange rates, gold prices from external environment and market beta, size, leverage, book to market equity and earning price ratio from internal environment.

\section{Data, Variable and Hypothised Relationships}

Based on literature review, this research found variables representing goods market, money market, foreign exchange market and domestic and global capital markets. Using relevant statistical test these sampled variables were finally reduced to manageable priori variables. The relationship of these variables is also hypothesized before reaching to conclusion and construction of a model.

\subsection{Data and Variable}

The rationale of this research was to identify strategic risk factors for Indian stock markets between April 1999 to March 2015 using monthly data series using Eviews 8.0, as longer series of data was not available and monthly data series seemed to be satisfactory for intended empirical analysis. The study found initially 16 relevant macroeconomic variables from available finance literature as a proxy of systematic risk factors to find the relevant systematic risk factors for Indian stock markets. Data related with wholesale price index (WPI), consumer price index (CPI), the industrial production index (IPI), money supply (M3), imports and exports to derive net exports (NX), net foreign institutional investment (FII), Foreign exchange reserve of Government, foreign exchange rate of Indian rupee with US dollar(EXRATE), Yield on 91-days treasury bills, Average monthly call money rates, interest rate on 10 years government bond, fiscal defi- 
cit of government of India, dividend yield of Indian markets, price earnings ratio of Indian markets (PE) and International crude oil prices (ICOP) were collected from database of Reserve Bank of India. Morgan Stanley capital market international world index (MSCI) was the proxy of global stock markets reflecting influence of global factors.

Finally seven factors were extracted from these 16 variables appropriate scrutiny and validation process represented as a priori variables. These final seven factors for the study were industrial production index (IPI), interest rate (INT) on 10 years government bonds, foreign exchange rate of Indian rupee with US dollar (EXRATE), CPI as proxy of Inflation, MSCI global index (MSCI), dividend yield (DY) and price earnings ratio of Indian stock market(PER). To validate the selection of these seven factors the study performed principal component analysis using SPSS 20.0. Although factors analysis reduced the sampled variables to five factors (IPI, INT, EXRATE, CPI and DY) only but refereeing the available literature two more additional factors MSCI and PE were employed. Table 1 depicts the variables used in the study:

\subsection{Hypothesized Relationship of Variables}

The industrial production index (IPI) is used as a proxy of goods market, interest rate (INT) on 10 years government bonds is used as a proxy of money market, foreign exchange rate of Indian rupee with US dollar (EXRATE) is used as a proxy of foreign exchange market, capital market is represented by SENSEX, dividend yield (DY) and price earnings ratio of Indian stock market (PER) and MSCI represented global financial markets. The hypothesized relationship of these variables is given in following Table 2.

The relationship of IPI with stock price is hypothesized positive as higher production leads to better performance of corporate resulting in higher profitability and stock prices. An increase in production out will lead to increased cash

Table 1. Description of variables.

\begin{tabular}{ccc}
\hline S. No. & Variable & Symbol \\
\hline 1 & Wholesale price index & WPI \\
2 & Consumer price index & CPI \\
3 & Industrial production index & IPI \\
4 & Money supply & M3 \\
5 & Net exports & NX \\
6 & Foreign institutional investment & FII \\
7 & Foreign exchange reserve of Government, & FOREX \\
8 & Net foreign exchange rate of Indian rupee with US dollar & EXRATE \\
9 & Price earnings ratio & P/E \\
10 & Dividend yield & DY \\
11 & MSCI global index & MSCI \\
\hline
\end{tabular}


Table 2. Hypothesized relationship with stock prices.

\begin{tabular}{cc}
\hline Variable & Hypothesized Relationship \\
\hline Industrial production index (IPI) & Positive (+) \\
Interest Rate (INT) & Negative $(-)$ \\
Exchange Rate (EXRATE) & Negative (-) \\
Consumer Price Index (CPI) & Negative (-) \\
MSCI & Positive (+) \\
Dividend yield & Positive (+) \\
Price Earnings ratio & Positive (+) \\
\hline
\end{tabular}

flows in the future. The relationship of interest rate and stock prices is hypothesized as negative because higher interest rates will lead to higher required rate of return for equity investors resulting in fall in stock prices. Also increase in interest rate will increase cost of capital for corporate and will put pressure on their profit margins. The relationship of foreign exchange rate with stock prices is hypothesized negative as Indian economy has negative trade balance and there is negative impact of stock market, whenever rupee is depreciated against dollar. Inflation is a double edge sword as it has some positive as well as negative impact on stock prices. But in India context higher inflation is directly linked with higher interest rate and vice versa. So relationship of CPI (proxy of inflation) with stock prices is hypothesized negative. The proxy of global financial market MSCI may affect Indian stock markets in either way (positively or negatively) but the study hypothesized a positive relationship of MSCI with stock prices. The study hypothesized a positive relation of dividend yield and price earning with stock prices. In short run after dividend announcement stock price may fall but in long run it has a positive impact on stock prices. Similarly high PR will boost confidence of investors leading to higher stock prices.

\subsection{Methodology}

A battery of econometric tests has been employed to analyse short-run and longrun integration of systematic risk factors for Indian stock market. Johansen cointegration method was used to analyze the long-run integration of Indian stock markets with identified systematic risk factors. The model chosen is mentioned below:

$$
\Delta \text { SENSEX }=\mathrm{f}(\Delta \mathrm{IPI}, \Delta \mathrm{INT}, \Delta \text { EXRATE }, \Delta \mathrm{CPI}, \Delta \mathrm{MSCI}, \Delta \mathrm{DY}, \Delta \mathrm{PER})
$$

However for further analysis of vector autoregressive model (VAR) that has constant but no trend and having breakpoint dummy as exogenous can be presented as follows:

$$
Y_{t}=\mu_{0}+\sum_{k=0}^{n} \beta_{i} Y_{t-i}+\phi D_{t}+u_{t}
$$

where

$Y_{t}=($ LNSENSEX, LNIPI, LNINT, LNEXRATE, LNCPI, LNMSCI, LNDY, LNPER $)$ 
A $8 \times 1$ vector of $\mathrm{I}(1)$ was the internal variable in the model and $D_{t}$ is breakpoint dummy external variable. $\mu_{0}$ and $\mu_{t}$ are constant and white noise respectively.

To conduct the Johansen cointegration analysis the VAR equation in (2) was turned into vector error correction model (VECM) by introducing an error correction term $E C M_{-1}$ in to the model. The new model is as follows:

$$
Y_{t}=\mu_{0}+\sum_{i=1}^{p-1} \dot{\Gamma}_{i} \Delta_{i} Y_{t-i}+\delta E C M_{-1}+\phi D_{t}+\varepsilon_{t}
$$

or,

$$
Y_{t}=\mu_{0}+\sum_{i=1}^{p-1} \Gamma_{i} \Delta_{i} Y_{t-i}+\alpha \beta^{\prime} Y_{t-1}+\phi D_{t}+\varepsilon_{t}
$$

where $\varepsilon_{t} \sim \operatorname{iidN}(0, \pi)$.

\subsection{Analysis and Findings}

\subsubsection{Descriptive Statistics}

The descriptive statistics of the eight variables (which include the seven independent variables and the SENSEX) are reported in Table 3.

\subsubsection{Correlation Analysis}

Table 4 shows correlation between stock market variable and variables representing systematic risk factors for Indian stock markets. Results suggest that except interest rate all other variables are significantly correlated with stock market variable at $1 \%$ level of significance. Although this study hypothesized negative relation of exchange rate and inflation with stock market variable but surprisingly all variables including exchange rate and inflation are positively correlated with stock market variables.

\subsubsection{Unit Root Tests}

The precondition of Johansen cointegration test was that the variables must be non-stationary at level and stationary at first difference. Conintegration analysis only uses variables those are non-stationary with unit root. The study tested that the used series are stationary or not with the help of unit root tests by using Augmented Dickey Fuller test (ADF) and Phillips-Perron test (PP). The study

Table 3. Descriptive statistics.

\begin{tabular}{ccccccccc}
\hline & LNSENSEX & LNIPI & LNINT & LNEXRT & LNCPI & LNMSCI & LNDY & LNPE \\
\hline Minimum & 7.9787 & 4.9857 & 1.6303 & 3.6731 & 6.0661 & 5.1797 & 0.7031 & 2.4749 \\
Maximum & 10.2734 & 5.9953 & 2.4757 & 4.1550 & 7.1460 & 6.0695 & 2.8356 & 3.3807 \\
Mean & 9.1663 & 5.5223 & 2.0667 & 3.8654 & 6.4842 & 5.7061 & 1.2351 & 2.9042 \\
Std. Deviation & 0.7121 & 0.3143 & 0.1904 & 0.1145 & 0.3407 & 0.2170 & 0.2957 & 0.1843 \\
& -0.2861 & -0.2302 & -0.0182 & 1.0291 & 0.5341 & -0.3911 & 0.9086 & 0.0173 \\
Skewness & 0.1754 & 0.1763 & 0.1754 & 0.1754 & 0.1768 & 0.1754 & 0.1873 & 0.1873 \\
& -1.4440 & -1.4753 & 0.3305 & 0.4579 & -1.1667 & -0.4781 & 3.9992 & -0.1886 \\
Kurtosis & 0.3491 & 0.3509 & 0.3491 & 0.3491 & 0.3518 & 0.3491 & 0.3725 & 0.3725 \\
\hline
\end{tabular}


Table 4. Correlations analysis.

\begin{tabular}{ccccccccc}
\hline & LNSENSEX & LNIPI & LNINT & LNEXRT & LNCPI & LNMSCI & LNDY & LNPE \\
\hline LNSENSEX & 1 & $0.951^{* *}$ & 0.045 & $0.383^{* *}$ & $0.878^{* *}$ & $0.747^{* *}$ & $0.586^{* *}$ & $0.403^{* *}$ \\
LNIPI & & 1 & -0.106 & $0.438^{* *}$ & $0.414^{* *}$ & $0.558^{* *}$ & $0.370^{* *}$ & $0.171^{*}$ \\
LNINT & & & & 0.038 & 0.040 & $0.436^{* *}$ & 0.145 & $0.430^{* *}$ \\
LNEXRT & & & & 1 & $0.697^{* *}$ & $0.221^{* *}$ & $-0.472^{* *}$ & $-0.435^{* *}$ \\
LNCPI & & & & 1 & $0.542^{* *}$ & $0.199^{* *}$ & 0.110 \\
LNMSCI & & & & & 1 & $0.773^{* *}$ & $0.716^{* *}$ \\
LNDY & & & & & & & 1 & $0.661^{* *}$ \\
LNPE & & & & & & & & 1 \\
\hline
\end{tabular}

${ }^{* *}$ Correlation is significant at the 0.01 level (2-tailed). ${ }^{*}$ Correlation is significant at the 0.05 level (2-tailed).

Table 5. Unit root test results.

\begin{tabular}{|c|c|c|c|c|c|c|}
\hline \multirow[b]{2}{*}{ Variables } & \multicolumn{3}{|c|}{ Augmented Dickey-Fuller (ADF) } & \multicolumn{3}{|c|}{ Phillips-Perron (PP) } \\
\hline & $\begin{array}{l}\text { Model A: } \\
\text { (intercept, } \\
\text { no trend) }\end{array}$ & $\begin{array}{c}\text { Model B: } \\
\text { (intercept } \\
\text { with trend) }\end{array}$ & $\begin{array}{l}\text { Model C: } \\
\text { (nointercept, } \\
\text { no trend) }\end{array}$ & $\begin{array}{l}\text { Model A: } \\
\text { (intercept, } \\
\text { no trend) }\end{array}$ & $\begin{array}{c}\text { Model B: } \\
\text { (intercept } \\
\text { with trend) }\end{array}$ & $\begin{array}{c}\text { Model C: } \\
\text { (nointercept, } \\
\text { no trend) }\end{array}$ \\
\hline \multicolumn{7}{|l|}{ At Level } \\
\hline LNSENSEX & -0.6123 & -2.2468 & 1.5644 & -0.7255 & -2.1090 & 1.8228 \\
\hline LNIPI & -1.1558 & -1.2804 & 1.8924 & -1.0025 & -5.0973 & 4.0377 \\
\hline LNINT & -2.3201 & -2.1930 & -0.9185 & -2.3659 & -2.2354 & -0.8932 \\
\hline LNEXRATE & -0.6811 & -1.4876 & -1.1023 & -0.2559 & -1.0877 & 1.3617 \\
\hline LNICPI & -0.3519 & -3.0923 & 1.1065 & -0.3758 & -0.2661 & 1.4213 \\
\hline LNMSCI & -1.4200 & -2.1245 & -0.4780 & -1.5679 & -2.3233 & -0.3938 \\
\hline LNDY & -2.0444 & -2.5523 & -0.5214 & -2.4346 & -2.7430 & 0.8648 \\
\hline LNPER & -1.8346 & -2.9635 & -0.2156 & -1.8475 & -2.5987 & 0.4182 \\
\hline \multicolumn{7}{|l|}{ At $1^{\text {st }}$ diff. } \\
\hline$\triangle$ LNSENSEX & -10.2151 & -10.1922 & -10.0453 & -10.1331 & -10.1083 & -10.0077 \\
\hline$\triangle$ LNIPI & -2.6483 & -2.8019 & -1.7286 & -38.8598 & -37.6794 & -26.6551 \\
\hline$\Delta \mathrm{LNINT}$ & -13.2368 & -13.2893 & -13.2402 & -13.2458 & -13.2868 & -13.2508 \\
\hline$\triangle$ LNEXRATE & -9.8222 & -9.8488 & -9.7512 & -9.8121 & -9.7945 & -9.7914 \\
\hline$\triangle \mathrm{LNCPI}$ & -8.3789 & -8.7853 & -8.2461 & -10.3723 & -10.2898 & 10.5744 \\
\hline$\Delta$ LNMSCI & -11.7645 & -11.7619 & -11.7749 & -11.9421 & -11.9310 & -11.9560 \\
\hline$\triangle \mathrm{LNDY}$ & -13.5936 & -13.5633 & -13.6356 & -24.5302 & -24.4684 & -24.6173 \\
\hline$\triangle \mathrm{LNPER}$ & -4.4205 & -4.3887 & -4.4167 & -6.5535 & --6.5088 & -6.5723 \\
\hline
\end{tabular}

MacKinnon critical values at level for model A is -2.9851 , model B -3.469 , model C -1.9439 and at $1^{\text {st }}$ difference for model A -2.8995 , model B -3.4626 and model C -1.9445 .

tested unit roots at level and at first difference with all three possible model related with intercept and trend. These three models were intercept with no trend, intercept with trend and no intercept no trend (Table 5). 


\subsection{Chow Breakpoint Test}

The time period selected for the study was 1999 to 2015, so it was important to test the break point test for the period January 2008(start of global financial crisis) and march 2009 (reversal of markets after global financial crisis). The Chow break point test was used the test the break point effect and the results of $\mathrm{F}$ statistics and corresponding p-values are given below (Table 6).

\subsection{Lag Length Analysis}

For conducting cointegration analysis consideration the choice of appropriate lag length is a very sensitive issue. There are many criteria for lag length selection. The study used Sequential modified like hood ratio test (LR), Final prediction error (FPE), Akaike information criterion (AIC), Schwarz Bayesian Criterion (SC) and Hannan-Quinn information criterion (HQ), and the outcome is mentioned in Table 7, LR statistics suggests that 4 lags should be considered, while FPE and AIC suggests that 2 lags should be considered. We selected lag length on 1 for our mode as total number of observation are not very large and it is in conformity with the available finance theory literature.

\subsection{Cointegration Analysis}

We conducted conintegration analysis and results are given in Table 8. Table 8(a) and Table 8(b) represents conintegration tests results maximum eigen value $\left(\lambda_{\max }\right.$ and Trace statistics $\left(\lambda_{\text {trace }}\right)$. The long run equation is shown in part C. In maximum eigen value test null hypothesis of $r=1$ is rejected against alternative hypothesis of $r=2$ in maximum eigen value test and $r=0$ against $r=1$ in

Table 6. Chow breakpoint test.

\begin{tabular}{|c|c|c|c|c|c|c|}
\hline \multicolumn{7}{|c|}{ Chow Breakpoint Test for 2008M01 } \\
\hline \multicolumn{4}{|c|}{ F-Statistics } & 25.2544 & probability & 0.0000 \\
\hline \multicolumn{4}{|c|}{ Log likelihood ratio } & 23.9418 & probability & 0.0000 \\
\hline \multicolumn{7}{|c|}{ Chow Breakpoint Test for 2009M03 } \\
\hline \multicolumn{4}{|c|}{ F-Statistics } & 10.1642 & probability & 0.0017 \\
\hline \multicolumn{4}{|c|}{ Log likelihood ratio } & 10.0034 & probability & 0.0016 \\
\hline Lag & $\log L$ & LR & FPE & AIC & SC & HQ \\
\hline 0 & 2284.521 & NA & $8.60 \mathrm{E}-23$ & -28.1052 & $-27.95272^{*}$ & -28.04329 \\
\hline 1 & 2429.966 & 274.7292 & $3.15 \mathrm{E}-23$ & -29.1107 & -27.7384 & $-28.55353^{\star}$ \\
\hline 2 & 2501.687 & 128.3906 & $2.88 \mathrm{E}-23$ & -29.206 & -26.614 & -28.1536 \\
\hline 3 & 2568.865 & 113.6215 & $2.80 \mathrm{e}-23^{*}$ & $-29.24525^{\star}$ & -25.4334 & -27.69758 \\
\hline 4 & 2620.982 & 83.0006 & $3.33 \mathrm{E}-23$ & -29.0985 & -24.0669 & -27.05562 \\
\hline 5 & 2683.357 & $93.17838^{*}$ & $3.55 \mathrm{E}-23$ & -29.0785 & -22.8271 & -26.54031 \\
\hline
\end{tabular}


Table 8. Cointegration Results (long run) for India. (a) Test statistics: maximal eigen value $\left(\lambda_{\max }\right)$; (b) Test statistics: Trace $\left(\lambda_{\text {trace }}\right)$; (c) The long run equation.

(a)

\begin{tabular}{ccccc}
\hline Hypothesized no of CE(s) & Eigenvalue & Trace Statistic & Critical Value (5\%) & Prob. $^{* *}$ \\
None $^{*}$ & 0.325617 & 196.5166 & 159.5297 & 0.0001 \\
At most $1^{*}$ & 0.208028 & 132.3016 & 125.6154 & 0.0183 \\
At most 2 & 0.186779 & 94.28521 & 95.75366 & 0.0629 \\
At most 3 & 0.141716 & 60.58466 & 69.81889 & 0.2178 \\
At most 4 & 0.092595 & 35.67488 & 47.85613 & 0.4129 \\
At most 5 & 0.07364 & 19.83671 & 29.79707 & 0.434 \\
At most 6 & 0.040772 & 7.368416 & 15.49471 & 0.5352 \\
At most 7 & 0.003572 & 0.583252 & 3.841466 & 0.445 \\
\hline Hypothesized no of CE(s) & Eigenvalue & Trace Statistic & Critical Value (5\%) & Prob. ${ }^{* *}$ \\
\hline None & 0.325617 & 64.21504 & 52.36261 & 0.0021 \\
At most 1 & 0.208028 & 38.01639 & 46.23142 & 0.287 \\
At most 2 & 0.186779 & 33.70055 & 40.07757 & 0.2189 \\
At most 3 & 0.141716 & 24.90978 & 33.87687 & 0.3911 \\
At most 4 & 0.092595 & 15.83817 & 27.58434 & 0.6795 \\
At most 5 & 0.07364 & 12.46829 & 21.13162 & 0.5022 \\
At most 6 & 0.040772 & 6.785164 & 14.2646 & 0.5149 \\
At most 7 & 0.003572 & 0.583252 & 3.841466 & 0.445 \\
\hline & & $(\mathrm{b})$ & & \\
\hline & & & & \\
\hline & & & & \\
\hline
\end{tabular}

(c)

$$
\begin{aligned}
\text { LNSENSEX } & -2.4631 \operatorname{LNIPI}_{(0.2696)}-0.0303 \operatorname{LNINT}_{(0.1357)}-1.0370 \operatorname{LNEXRATE}_{(0.3792)} \\
& +0.6088 \operatorname{LNCPI}_{(0.2897)}+0.3490 \operatorname{LNMSCI}_{(0.2433)} \\
& -0.7850 \operatorname{LNDY}_{(0.1713)}-0.6971 \operatorname{LNPE}_{(0.1581)}
\end{aligned} .
$$

*denotes rejection of the hypothesis at the 0.05 level, ${ }^{* *}$ MacKinnon-Haug-Michelis [34] p-values.

trace test. The result depicts that only one stationary linear combination is integrated in long run. In Johansen [33] conintegration analysis the coefficient on conintegration equation are normalized.

Results of dynamic series are given in Table 9 and short run equilibrium position of India is given in Table 10 and Figure 1. Table 9 present coefficient of long term parameter $\beta$ upon normalization for LNSENSEX. The coefficient for LNSENSEX, LNIPI, LNGSECR, LNEXRATE, LNCPI, LNMSCI, LNDY and LNPE are $-1.2446,-0.1337,0.7494,-0.7112,0.1248,-0.8281$ AND -0.0685 respectively. The corresponding t-statistics are 10.6942, 0.5627, $-15.2996,7.53949$, 3.74307, 7.22788 and 1.79791 respectively. The results suggest that except LNGSECR all other variables LNIPI, LNEXRATE, LNCPI, LNMSCI, LNDY AND LNPE are significant in and have long term conintegration with LNSENSEX. 
Table 9. Results (Long-Run) for India.

\begin{tabular}{cccc}
\hline Variables & Coefficient & SE & t-value $^{*}$ \\
\hline LNSENSEX & 1.0000 & & \\
LNIPI & -1.2446 & -0.1518 & 10.6942 \\
LNGSECR & -0.1337 & -0.0792 & 0.5627 \\
LNEXRATE & 0.7494 & -0.2268 & -15.2996 \\
LNCPI & -0.7112 & -0.1635 & 7.5394 \\
LNMSCI & 0.1248 & -0.1315 & 3.7430 \\
LNDY & -0.8281 & -0.0858 & 7.2278 \\
LNPE & -0.0685 & -0.0889 & 1.7979 \\
\hline
\end{tabular}

${ }^{*}$ Critical values for $\mathrm{t}$-statistics ( 2 sided test) are 1.96 and 1.58 at $5 \%$ and $1 \%$ level of significance.

Table 10. Results (Short-Run) for India.

\begin{tabular}{ccccc}
\hline Variables & Coefficient & Standard Error & t statistics & p-value \\
\hline LHS variable: $\Delta$ LNSENSEX & & & & \\
DLNSENSEX (-1) & 0.2366 & 0.140568 & 1.6836 & 0.0944 \\
$\Delta$ LNIPI(-1) & 0.1173 & 0.113577 & 1.0334 & 0.3031 \\
$\Delta$ LNGSECR(-1) & 0.1307 & 0.105056 & 1.2444 & 0.2153 \\
$\Delta$ LNEXRATE(-1) & -0.0282 & 0.35586 & -0.0793 & 0.9369 \\
$\Delta$ LNCPI(-1) & -0.7898 & 0.414722 & -1.9044 & 0.0588 \\
$\Delta$ LNMSCI(-1) & 0.5553 & 0.108698 & 5.1094 & 0.0000 \\
$\Delta$ LNDY(-1) & 0.0429 & 0.043512 & 0.9867 & 0.3254 \\
$\Delta$ LNPE(-1) & -0.1347 & 0.111891 & -1.2039 & 0.2305 \\
ECM(-1) & 0.0787 & 0.061231 & 1.2858 & 0.2005 \\
\hline
\end{tabular}

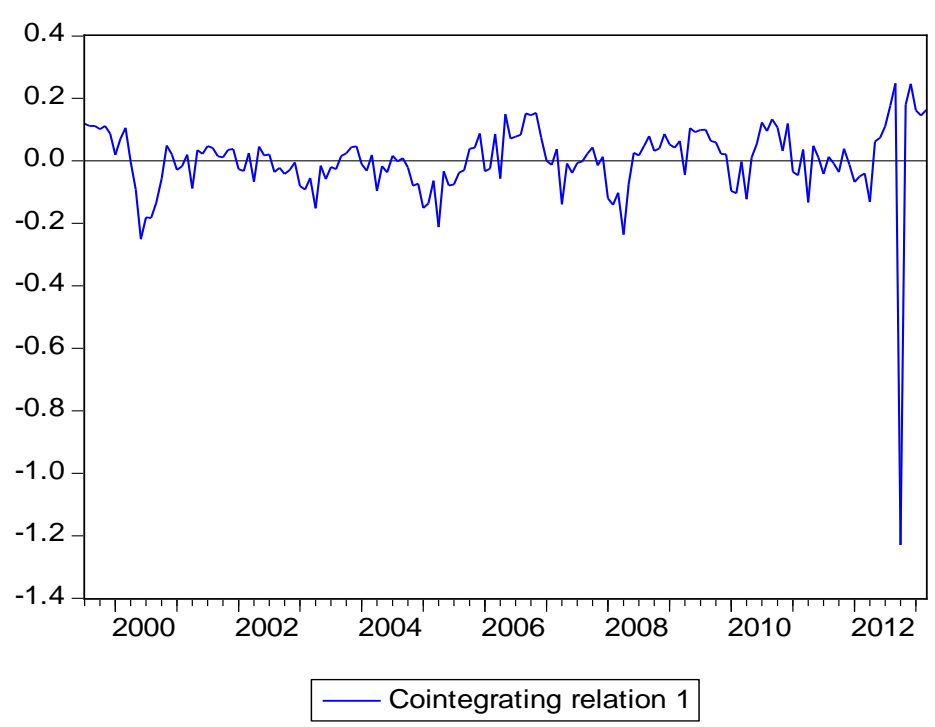

Figure 1. State of equilibrium pricing in indian stock market. The conintegration plot shows the pattern of cointegration between systematic risk factors and Indian stock market. 
Table 10 depicts estimates of short run parameter on Indian stock markets. The coefficients of $\triangle$ LNSENSEX $(-1), \Delta \operatorname{LNIPI}(-1), \triangle \operatorname{LNGSECR}(-1)$, $\triangle$ LNEXRATE $(-1), \Delta$ LNCPI $(-1), \triangle \operatorname{LNMSCI}(-1), \Delta$ LNDY $(-1)$ and $\Delta$ LNPE $(-1)$ are $0.2366,0.1173,0.1307,-0.0282,-0.7898,0.5553,0.0429$ and -0.1347 respectively. The corresponding t-statistics are 1.6836, 1.0334, 1.2444, -0.0793 , $-1.9044,5.1094,0.9867$ and -1.2039 respectively. The results clearly indicate short term adjustments of Indian stock market $\triangle$ LNSENSEX (-1), $\triangle$ LNMSCI $(-1)$ and $\triangle$ LNCPI $(-1)$ are significant at $10 \%, 1 \%$ and $5 \%$ level of significance respectively. Results indicate that Indian stock prices are adjusted monthly by its previous month levels as well as previous month's global stock markets and consumer price index (inflation).

The short run dynamics estimated coefficient of a corresponding to $\triangle$ LNSENSEX, $\triangle$ LNIPI, $\triangle$ LNGSECR, $\triangle$ LNEXRATE, $\triangle$ LNCPI, $\triangle$ LNMSCI, $\triangle$ LNDY and $\triangle$ LNPE are $0.0787,-0.0979,-0.01053,0.0590,-0.0559,0.0098,-0.0652$ and -0.0053 respectively. The corresponding t-statistics values are $0.8020,-1.4589,-1.8516$, $0.4968,0.2498,2.0634,-0.2531,-3.1853$ respectively. The details are given in following equation:

$$
\begin{aligned}
\alpha^{\wedge}= & {\left[\alpha_{11}, \alpha_{21}, \alpha_{31}, \alpha_{41}, \alpha_{51}, \alpha_{61}, \alpha_{71}, \alpha_{81}\right] } \\
= & {\left[0.07873_{0.8020},-0.0979_{-1.4589},-0.0105_{-1.8516}, 0.0590_{0.4967},\right.} \\
& \left.-0.0559_{0.2498}, 0.0098_{2.0634},-0.0652_{-0.2531},-0.0053_{-3.1853}\right]
\end{aligned}
$$

On the basis of all above results of long run dynamic and short run dynamics of Indian stock markets vector error correction model (VECM) for Indian stock market is given below in Equation (8) and the solved equation is given in (9):

$$
\begin{aligned}
& \Delta(\text { LNSENSEX })=0.0787 *[\operatorname{LNSENSEX}(-1)-1.2446 * \operatorname{LNIPI}(-1) \\
& -0.1337 * \operatorname{LNGSECR}(-1)+0.7494 * \operatorname{LNEXRT}(-1)-0.7112 * \operatorname{LNCPI}(-1) \\
& +0.1248 * \operatorname{LNMSCI}(-1)-0.8281 * \operatorname{LNDY}(-1)-0.0685 * \operatorname{LNPE}(-1)+0.2532] \\
& +0.2366 * \Delta(\operatorname{LNSENSEX}(-1))+0.1173 * \Delta(\operatorname{LNIPI}(-1))+0.1307 * \Delta(\operatorname{LNGSECR}(-1)) \\
& -0.0282 * \Delta(\operatorname{LNEXRT}(-1))-0.7898 * \Delta(\operatorname{LNCPI}(-1))+0.5553 * \Delta(\operatorname{LNMSCI}(-1)) \\
& +0.0429 * \Delta(\operatorname{LNDY}(-1))-0.1347 * \Delta(\operatorname{LNPE}(-1))+0.0107 \\
& \text { or } \quad \\
& \Delta(\operatorname{LNSENSEX})=0.0787 * \operatorname{LNSENSEX}(-1)-0.0979 * \operatorname{LNIPI}(-1) \\
& -0.0105 * \operatorname{LNGSECR}(-1)+0.5897 * \operatorname{LNEXRT}(-1)-0.0559 * \operatorname{LNCPI}(-1) \\
& +0.0098 * \operatorname{LNMSCI}(-1)-0.0651 * \operatorname{LNDY}(-1)-0.0054 * \operatorname{LNPE}(-1) \\
& +0.0199+0.2366 * \Delta(\operatorname{LNSENSEX}(-1))+0.1173 * \Delta(\operatorname{LNIPI}(-1)) \\
& +0.1307 * \Delta(\operatorname{LNGSECR}(-1))-0.0282 * \Delta(\operatorname{LNEXRT}(-1)) \\
& -0.7898 * \Delta(\operatorname{LNCPI}(-1))+0.5553 * \Delta(\operatorname{LNMSCI}(-1)) \\
& +0.0429 * \Delta(\operatorname{LNDY}(-1))-0.1347 * \Delta(\operatorname{LNPE}(-1))+0.0107
\end{aligned}
$$

The above results can help in understanding return generating process in Indian stock markets. The long run conintegration analysis results suggests that 
industrial production, foreign exchange rate, inflation, dividend yield, price earnings ratio and global financial markets have significant impact on Indian stock markets.

\section{Conclusions}

The objective of this study was to identify risk factors for Indian stock markets. The results of the study are encouraging and highly useful for investors in pricing the market. These results are in line with existing finance literature with different on some points. The study identified seven relevant variables representing systematic risk factor for Indian stock markets, namely industrial production index (IPI), interest rate (INT) on ten years government bonds, foreign exchange rate of Indian rupee with US dollar (EXRATE), CPI as proxy of Inflation, MSCI global index (MSCI), dividend yield (DY) and price earnings ratio of Indian stock market (PER) for Indian stock market. Some of these variables have short term while some others have long term impact on return generation process of Indian stock markets. The results of short run analysis suggests that Indian stock prices are adjusted monthly by its previous month levels, previous month's global stock markets and consumer price index (inflation). Accordingly, the study concluded that there are three major factors and their lagged values influencing short term return generating process namely previous month's levels of markets index itself (SENSEX), global markets (MSCI global) and inflation (CPI). However, in long run there are six major factors influencing return generating process namely industrial production index, foreign exchange rate, inflation, dividend yield, price rearing ratio and global financial markets. Hence, while making short term and long term investment decision predictability of these risk factors will help investors in understanding return generation potential of Indian stock markets.

The study significantly contributes in existing literature on risk factors for stock market of emerging economy like India. The findings of the study are significant for investors, fund managers and analysts for pricing risk in their investment decisions and analysing systematic risk factors. Findings of this study cannot be the only criterion for any investment decision so investors must consider several others quantitative and qualitative factors that may affect return generating process of Indian stock markets.

\section{References}

[1] Ross, S.A. (1976) The Arbitrage Theory of Capital Asset Pricing. Journal of Economic Theory, 13, 341-360. https://doi.org/10.1016/0022-0531(76)90046-6

[2] Roll, R. and Ross Stephen, A. (1980) An Empirical Investigation of the Arbitrage Pricing Theory. Journal of Finance, 35, 1073-1103. https://doi.org/10.1111/j.1540-6261.1980.tb02197.x

[3] Alexander, G.J., Sharpe, W.F. and Bailey, J.V. (2001) Fundamentals of Investments. 3rd Edition, Prentice-Hall, Englewood Cliffs.

[4] Sharpe, W.F. (1964) Capital Asset Prices: A Theory of Market Equilibrium under 
Conditions of Risk. Journal of Finance, 19, 425-442.

[5] Lintner, J. (1965) The Valuation of Risk Assets and the Selection of Risky Investments in Stock Portfolios and Capital Budgets. Review of Economics and Statistics, 47, 13-37. https://doi.org/10.2307/1924119

[6] Black, F., Jensen, M.C. and Scholes, M. (1972) The Capital Asset Pricing Model: Some Empirical Tests. Studies in the Theory of Capital Markets, 79-121.

[7] Mossin, J. (1966) Equilibrium in a Capital Asset Market. Econometrica, 35, 768-783. https://doi.org/10.2307/1910098

[8] Stattman, D. (1980) Book Values and Stock Returns. The Chicago MBA: A Journal of Selected Papers, 4, 25-45.

[9] Rosenberg, B., Reid, K. and Lanstein, R. (1985) Persuasive Evidence of Market Inefficiency. Journal of Portfolio Management, 11, 9-17. https://doi.org/10.3905/jpm.1985.409007

[10] Chen, N.F., Roll, R. and Ross, S.A. (1986) Economic Forces and the Stock Market. Journal of Business, 59, 383-403. https://doi.org/10.1086/296344

[11] Darrat, A.F. and Mukherjee, T.K. (1987) The Behavior of the Stock Market in a Developing Economy. Economics Letters, 22, 273-278.

[12] Chan, L.K.C., Hamao, Y. and Lakonishok, J. (1991) Fundamentals and Stock Returns in Japan. Journal of Finance, 46, 1739-1789. https://doi.org/10.1111/j.1540-6261.1991.tb04642.x

[13] Poon, S. and Taylor, S.J. (1991) Macroeconomic Factors and the UK Stock Market. Journal of Business and Accounting, 18, 619-636. https://doi.org/10.1111/j.1468-5957.1991.tb00229.x

[14] Fama, E.F. and French, K.R. (1992) The Cross-Section of Expected Stock Returns. Journal of Finance, 47, 427-465. https://doi.org/10.1111/j.1540-6261.1992.tb04398.x

[15] Mukherjee, T. and Naka, A. (1995) Dynamic Linkage between Macroeconomic Variables and the Japanese Stock Market: An Application of a Vector Error Correction Model. Journal of Financial Research, 18, 223-237. https://doi.org/10.1111/j.1475-6803.1995.tb00563.x

[16] Naka, A., Mukherjee, T.K. and Tufte, D. (1998) Macroeconomic Variables and the Performance of the Indian Stock Market. Working Paper, University of New Orleans.

[17] Gjerde, Ø. and Sættem, F. (1999) Causal Relations among Stock Returns and Macroeconomic Variables in a Small, Open Economy. Journal of International Financial Markets, Institutions \& Money, 9, 61-74.

[18] Panda, C. and Kamaiah, B. (2001) Monetary Policy, expected Wholesale Price Index, Real Activity and Stock Returns in India: An Empirical Analysis. Asian African Journal of Economics and Econometrics, 1, 191-200.

[19] Flannery, M.J. and Protopapadakis, A. (2002) Macroeconomic Factors Do Influence Aggregate Stock Returns. The Review of Financial Studies. Oxford University Press, Oxford, 751-782.

[20] Wongbangpo, P. and Sharma, C.S. (2002) Stock Market and Macroeconomic Fundamental Dynamic Interactions: ASEAN-5 Countries. Journal of Asian Economics, 13, 27-51.

[21] Mukhopadhyay, D. and Sakar, N. (2003) Stock Returns and Macroeconomic Fundamentals in Model Specification Framework: Evidence from Indian Stock Market. Indian Statistical Institute, Economic Research Unit, ERU 2003-2005 Discussion Paper, January, 1-28. 
[22] Maghrebi, N., Holmes, M.J. and Pentecost, E.J. (2006) Are There Asymmetries in the Relationship between Exchange Rate Fluctuations and Stock Market Volatility in Pacific Basin Countries? Review of Pacific Basin Financial Markets and Policies, 9, 229-256. https://doi.org/10.1142/S0219091506000719

[23] Dash, M. and Dinesh, K.G. (2008) A Study on the Effect of Macroeconomic Variables on Indian Mutual. International Journal of Economics and Financial Issues, 3, 191-201.

[24] Kim, S.-J. and Nguyen, D.Q.T. (2009) The Spillover Effects of Target Interest Rate News from the U.S. Fed and the European Central Bank on the Asia-Pacific Stock Markets. Journal of International Financial Markets, Institutions and Money, 19, 415-431.

[25] Srivastava, A. (2010) Relevance of Macro Economic Factors for the Indian Stock Market. Decision, 37, 69-89.

[26] Basu, D. and Chawla, D. (2012) An Empirical Study of Arbitrage Pricing Theory-The Case of Indian Stock Market. Global Business Review, 13, 421-432. https://doi.org/10.1177/097215091201300305

[27] Wen-jen, H. (2013) The Stock Market and Macroeconomic Variables in New Zealand and Policy Implications. Journal of International and Global Economic Studies, 6, 1-12.

[28] Pethe, A. and Karnik, A. (2000) Do Indian Stock Market Maters? Stock Market Indices and Macroeconomic Variables. Economic and Political Weekly, 35, 349-356.

[29] Bhattacharyya, B. and Mukherjee, J. (2006) Indian Stock Price Movement and the Macroeconomic Context-A Time Series Analysis. Journal of International Business and Economics, 5, 167-181.

[30] Ahmed, S. (2008) Aggregate Economic Variables and Stock Market in India. International Research Journal of Finance and Economics, 14, 14-64.

[31] Pal, K. and Mittal, R. (2011) Impact of Macroeconomic Indicators on Indian Capital Markets. Journal of Risk Finance, 12, 84-97. https://doi.org/10.1108/15265941111112811

[32] Shiva, A. and Sethi, M. (2015) Understanding Dynamic Relationship among Gold Price, Exchange Rate and Stock Markets: Evidence in Indian Context. Global Business Review, 16, 93-111. https://doi.org/10.1177/0972150915601257

[33] Johansen, S. (1995) Likelihood-Based Inference in Cointegrated Vector Autoregressive Models. Oxford University Press, Oxford. https://doi.org/10.1093/0198774508.001.0001

[34] MacKinnon, J.G., Haug, A.A. and Michelis, L. (1999) Numerical Distribution Functions of Likelihood Ratio Tests for Cointegration. Journal of Applied Econometrics, 14, 563-577.

https://doi.org/10.1002/(SICI)1099-1255(199909/10)14:5<563::AID-JAE530>3.0.CO $\underline{; 2-\mathrm{R}}$ 